\title{
Effect of Bactericides on Population Sizes and Spread of Clavibacter michiganensis subsp. michiganensis on Tomatoes in the Greenhouse and on Disease Development and Crop Yield in the Field
}

\author{
M. K. Hausbeck, J. Bell, C. Medina-Mora, R. Podolsky, and D. W. Fulbright
}

First, second, third, and fifth authors: Department of Botany and Plant Pathology, Michigan State University, East Lansing 48824-1312; and fourth author: Department of Biology, University of Michigan-Flint, Flint 48502.

Accepted for publication 27 September 1999.

\begin{abstract}
Hausbeck, M. K., Bell, J., Medina-Mora, C., Podolsky, R., and Fulbright, D. W. 2000. Effect of bactericides on population sizes and spread of Clavibacter michiganensis subsp. michiganensis on tomatoes in the greenhouse and on disease development and crop yield in the field. Phytopathology 90:38-44.

Chemical applications, with the exception of mancozeb, reduced population sizes and spread of Clavibacter michiganensis subsp. michiganensis among tomato seedlings in the greenhouse and impacted subsequent plant development and yield in the field. While applications of copper hydroxide, copper hydroxide/mancozeb, copper hydroxide/mancozeb (premixed

lated control, the trend was for these treatments to increase the survival of inoculated transplants in the field in comparison to the inoculated control. In the field, inoculated controls produced yields that were 63\% (1995) and $51 \%$ (1996) of those produced by uninoculated controls. In both years, with the exception of mancozeb in 1995, all treatments resulted in yields similar to those obtained with the uninoculated control. Plant survival and yield in the field were severely affected when transplants had a pathogen population of $\geq 1 \times 10^{8} \mathrm{CFU} / \mathrm{g}$ of tissue. All treatments, with the exception of mancozeb, limited C. michiganensis subsp. michiganensis populations to $<5.0 \times 10^{5}$. None of the treatments significantly reduced the incidence of fruit spotting compared with that of the inoculated control.
\end{abstract} $12 \mathrm{~h}$ before spraying), streptomycin, and streptomycin/copper hydroxide to seedlings in the greenhouse did not differ significantly from the inocu-

Bacterial canker, caused by Clavibacter michiganensis subsp. michiganensis, can be a limiting factor in the production of tomatoes grown for processing in Michigan. A seedling infected with C. michiganensis subsp. michiganensis may wilt and die shortly after transplanting to the field or may survive to produce a stunted plant that eventually succumbs to the disease. Stunted plants typically produce fruit that are reduced in size and quantity. In some cases, diseased fields cannot be harvested, because the stunted fruit are too small to be picked up by the mechanical harvester.

Although bacterial canker was first reported in 1909 on tomatoes growing in a greenhouse in Grand Rapids, MI, this disease can be found nearly everywhere tomatoes are grown (22). Historically, tomatoes were direct-seeded in outdoor transplant production beds in Georgia and Florida and routinely clipped or pruned to produce short, thick-stemmed, hardy transplants that could be shipped to growers in the Midwest and Canada to establish production fields. However, following a 1984 outbreak of bacterial canker throughout the Midwest and several Canadian provinces, which was traced to certified transplants from Georgia (9), Michigan growers began to produce transplants in local greenhouses. Today, with few exceptions, seedlings for Michigan are grown in local greenhouses constructed of clear polyethylene plastic. To maximize the use of space, seedlings are grown in 288-cell flats containing soilless medium and placed on the greenhouse floor leaving only minimal walkways.

Producing tomato transplants in local greenhouses has not eliminated bacterial canker, and growers of processing tomatoes in Michigan continue to suffer losses sporadically, which may total as much as $\$ 300,000$ for one grower in a single year. Growers who

Corresponding author: M. K. Hausbeck; E-mail address: hausbec1@ pilot.msu.edu

Publication no. P-1999-1025-02R

(C) 2000 The American Phytopathological Society
Additional keywords: bacterial canker.

believed producing transplants in local greenhouses would guarantee healthy transplants did not consider that $C$. michiganensis subsp. michiganensis may be seedborne and that even a low $(0.01 \%)$ transmission rate from seed to seedling can initiate a serious epidemic in tomato production fields $(2,9)$. Furthermore, the warm, humid growing environment of the greenhouse coupled with frequent overhead irrigation maximizes bacterial growth and spread among the closely spaced seedlings.

Growers have limited options in managing bacterial canker in the field. Few commercially grown cultivars have significant tolerance or resistance to C. michiganensis subsp. michiganensis (10). Michigan growers routinely employ cultural management recommendations for bacterial canker control that include fall plowdown of infected plants and rotation away from solanaceous crops for at least 2 years (10). Although some growers apply bactericides preventively, others initiate applications following the appearance of disease symptoms. Use of bactericides typically includes applications of copper products, either alone or mixed with the protectant fungicide mancozeb, every 7 to 10 days. Results from a study conducted in Florida in the mid-1960s suggested that the combination of copper and mancozeb was more effective than copper alone for control of bacterial spot of tomato caused by Xanthomonas campestris pv. vesicatoria and have served as the basis for control recommendations for other bacterial diseases $(5,11)$. Some growers have maintained that premixing copper and mancozeb a few hours prior to application increases the effectiveness of the combination for control of bacterial diseases. Shoemaker (20) determined that applications of copper products, either alone or mixed with protectant fungicides, every 5 to 7 days in the field can reduce the less severe bacterial canker symptoms of foliar blight and fruit spotting in North Carolina.

In our studies, tomato transplants growing in the greenhouse were targeted for disease management, because our observations indicated that the most severe bacterial canker epidemics were the re- 
sult of using infected seedlings to establish production fields. Furthermore, we believed that greenhouse culture of seedlings, with close plant spacing and wet, humid conditions, was more favorable for $C$. michiganensis subsp. michiganensis growth and dissemination than was the lower humidity and increased plant spacing found in Michigan production fields. Information regarding the impact of bactericides on $C$. michiganensis subsp. michiganensis on greenhouse seedlings is lacking. Although applications of bactericides to field-grown transplants have been tested for efficacy as pre- and postclip sprays (7), these results have little application to greenhouse-grown transplants that are not clipped. The objective of our study was to assess the impact of bactericides when applied to tomato seedlings in the greenhouse on subsequent $C$. michiganensis subsp. michiganensis populations in the field and on the resulting yield increases.

\section{MATERIALS AND METHODS}

Pathogen culture and inoculum preparation. The C. michiganensis subsp. michiganensis strain used was a rifampicin-resistant mutant of a rep-polymerase chain reaction (PCR) fingerprint type B strain isolated in 1987 from tomato fruit from a farm in northeastern Ohio. This strain has a BOX-PCR DNA fingerprint that is different from strains of $C$. michiganensis subsp. michiganensis commonly encountered in Michigan (15). The spontaneous rifampicin-resistant mutation was selected by plating cells from a nutrient broth yeast extract (NBY) broth culture modified by omitting glucose (MNBY) (15) on MNBY agar containing $50 \mu \mathrm{g}$ of rifampicin per $\mathrm{ml}$. The strain was tested for pathogenicity to tomato by clipping the petioles of 10- to 14-day-old seedlings with scissors dipped in a suspension of the strain, which had been grown in MNBY broth, centrifuging at $1,564 \times g$ for $10 \mathrm{~min}$ at room temperature in a GSA rotor in a Sorvall RC5C centrifuge (DuPont Co., Wilmington, DE), resuspending in sterile distilled water, and adjusting spectrophotometrically to approximately $3 \times 10^{8} \mathrm{CFU} / \mathrm{ml}$.

The $C$. michiganensis subsp. michiganensis strain used in the greenhouse experiments was prepared by inoculating two 5-ml broth cultures of MNBY containing $100 \mu \mathrm{g}$ of rifampicin per $\mathrm{ml}$ and incubating them for $48 \mathrm{~h}$ at room temperature with shaking at $190 \mathrm{rpm}$. These cultures were used to inoculate 1 liter of MNBY that was incubated $48 \mathrm{~h}$ at $25^{\circ} \mathrm{C}$ with shaking at $75 \mathrm{rpm}$. The culture was centrifuged and the pellets were resuspended and combined in sterile deionized water to a final volume of 1 liter; the final concentration was approximately $5 \times 10^{8} \mathrm{CFU} / \mathrm{ml}$.

Experimental design and bactericide sprays. On 3 April 1995 and 11 March 1996, plastic plug sheets $(52.5 \times 26.5 \times 4.0 \mathrm{~cm})$ containing 288 cells filled with soilless medium were seeded with the tomato cv. Heinz 8704 and germinated for 3 days in a walk-in germination chamber in a commercial greenhouse in southwestern Michigan. Plug sheets were then transported to a commercial polyethylene greenhouse (approximately $12.2 \times 29.3 \mathrm{~m}$ ) in Stockbridge, MI, where they were placed on overturned plastic flats on the earthen greenhouse floor that was covered with a black woven polyethylene groundcover. The flats were arranged in blocks, each consisting of 15 plug sheets (Fig. 1). Seedlings were watered overhead as required, and seedlings were irrigated with a 200-ppm $\mathrm{N}$ and $\mathrm{K}_{2} \mathrm{O}$ fertilizer solution (Peter's 20-20-20; Grace-Sierra Horticultural Products Co., Milpitas, CA) as needed. Greenhouse temperatures were maintained at $21 \pm 6^{\circ} \mathrm{C}$.

The study was arranged in a block design, with four replicates per treatment. The inner six $(2 \times 3)$ plug sheets of each block were targeted for treatment, with the surrounding flats considered as buffers between blocks (Fig. 1). The following treatments were investigated on $C$. michiganensis subsp. michiganensis-inoculated plants: (i) no treatment (control); (ii) mancozeb (Dithane F-45, $2.3 \mathrm{ml}$ a.i./liter; Rohm and Haas Co., Philadelphia); (iii) copper hydroxide (Kocide 40DF, $3.0 \mathrm{~g}$ a.i./liter; Griffin LLC, Valdosta, GA); (iv) mancozeb (Dithane F-45, $2.3 \mathrm{ml}$ a.i./liter) mixed with copper hydroxide (Kocide
40DF, $3.0 \mathrm{~g}$ a.i./liter); (v) streptomycin (Agri-mycin 17, $0.25 \mathrm{~g}$ a.i./ liter; Novartis Crop Protection, Inc. Ag. Products, Greensboro, NC); (vi) streptomycin (Agri-mycin 17, $0.25 \mathrm{~g}$ a.i./liter) mixed with copper hydroxide (Kocide 40DF, $3.0 \mathrm{~g}$ a.i./liter); and (vii) mancozeb (Dithane F-45, $2.3 \mathrm{ml}$ a.i./liter) premixed with copper hydroxide (Kocide 40DF, $3.0 \mathrm{~g}$ a.i./liter) $12 \mathrm{~h}$ prior to spraying. Untreated, uninoculated control plants were grown in a separate greenhouse under environmental and cultural conditions similar to those of the inoculated treatments.

Bactericide sprays were applied using a $\mathrm{CO}_{2}$ backpack sprayer with a single nozzle (1995 trial) or two flat-fan 8002 nozzles (TeeJet, Chicago) (1996 trial) that were operated at $2.8 \mathrm{~kg} / \mathrm{cm}^{2} \mathrm{de}-$ livering approximately 748 liters/ha. Bactericide sprays were initiated when the first true leaves of the seedlings were visible and prior to $C$. michiganensis subsp. michiganensis inoculation. Subsequent sprays were applied every 5 days (25 April to 4 June 1995; 5 April to 10 May 1996) until the seedlings were removed from the greenhouse and planted in the field.

Inoculation. In 1995 (24 April), tomato seedlings to be inoculated were removed from the commercial greenhouse and maintained in a growth chamber at $25^{\circ} \mathrm{C}$ (approximately $85 \%$ relative humidity) with a 12-h photoperiod for 3 days. In 1996 (8 April), seedlings to be inoculated were grown in a research greenhouse at $20^{\circ} \mathrm{C}$ until the time of inoculation.

Seedlings were sprayed with deionized water using a spray bottle and then inoculated by misting a $C$. michiganensis subsp. michiganensis suspension (prepared as described above) using a Preval pressurized sprayer (Precision Valve Corporation, Yonkers, NY) on the leaves. The first true leaf of each individual seedling was then removed by clipping the petiole next to the stem with scissors dipped in the same $C$. michiganensis subsp. michiganensis suspension. Inoculated seedlings were incubated in a growth chamber at $25^{\circ} \mathrm{C}$ for 3 days in 1995 and overnight on a laboratory bench in loosely closed plastic bags in 1996. To initiate infection in the commercial greenhouse, 16 seedlings with their soilless plugs and roots intact were removed from each of the two opposite corners of each treatment block and replaced with the same number of inoculated seedlings to establish inoculum foci (Fig. 1).

Sampling of greenhouse seedlings. At 43 days (1995) and 34 days (1996) after inoculation, six to eight seedlings were removed from

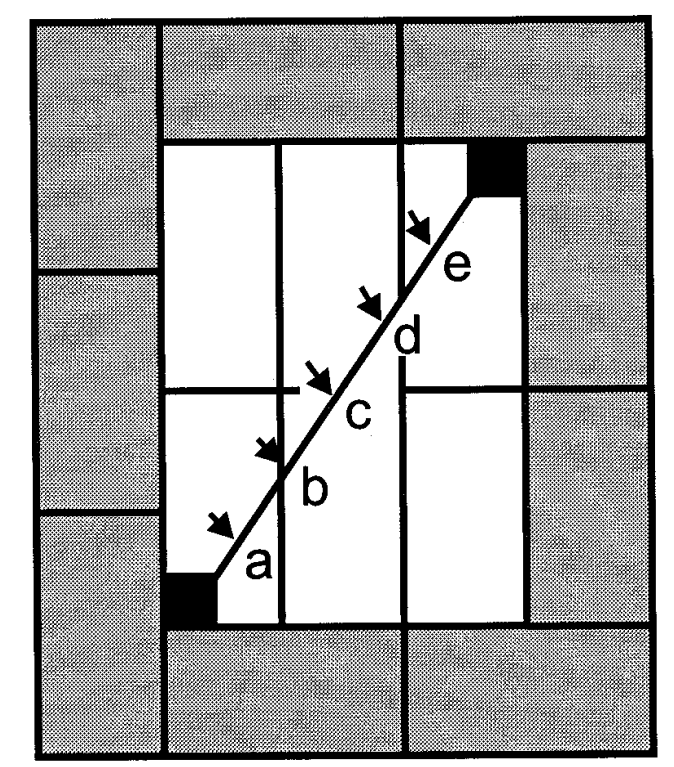

Fig. 1. Diagram of a treatment block with shaded areas serving as a buffer between blocks and each rectangle representing a $52.5 \times 26.5-\mathrm{cm}$ tray containing 288 tomato seedlings. Seedlings were sampled from each block following the diagonal (regions a to e; distance between each pair of arrows is $25 \mathrm{~cm}$ ) between the Clavibacter michiganensis subsp. michiganensis inoculum foci (ם). 
five regions (a to e) within each block along the diagonal between the inoculum foci (Fig. 1, regions a to e). The inoculated plants used to initiate disease within each treatment block were not included in the foliar samples; they were dead by the time of sampling. Samples from each region were stored individually in plastic bags in a cooler at $4^{\circ} \mathrm{C}$ for a maximum of 3 days; each sample was individually processed. Shoots and leaves were chopped and homogenized for $2 \mathrm{~min}$ in a Lab-Blender 400 stomacher (Tekmar Co., Cincinnati, $\mathrm{OH})$ using phosphate buffer $(0.05 \mathrm{M}, \mathrm{pH} 7.4 ; 2 \mathrm{ml} / \mathrm{g}$ of plant tissue) amended with Tween-20 detergent (0.02\%). Each sample was subjected to a 10 -fold serial dilution and the diluted samples spread on MNBY agar containing $100 \mu \mathrm{g}$ of rifampicin per ml.

Population densities were estimated from serial dilutions spread on MNBY-rifampicin agar. Due to production of copious extracellular polysaccharide, C. michiganensis subsp. michiganensis colonies readily become fluidal and coalesce on agar surfaces, making it difficult to count CFU accurately on crowded plates. This problem was particularly acute in 1995; therefore, we estimated the number of CFU as being between 1 and 10, between 10 and 100, and between 100 and 1,000 (confluent growth). The appropriate dilution factors were applied to these estimates to calculate the population density.
Untreated, uninoculated control plants were sampled by randomly removing six seedlings from each of 20 locations within several flats (1995) or by taking four samples from one flat (1996) and processing as previously described. Serially diluted homogenates were plated on MNBY agar. In 1995, 14 colonies resembling C. michiganensis subsp. michiganensis were chosen for BOX-PCR DNA fingerprinting and none were the pathogen. There were no colonies resembling C. michiganensis subsp. michiganensis in 1996.

Data were analyzed as a completely randomized split-plot design with blocks as main plots, main plots differing by treatment, and position used as a subplot. Because the variances were not equal, an analysis of variance (ANOVA) of the rank of the number of CFU was conducted (6) (Proc Rank and Proc GLM [SAS Institute, Cary, NC] with the following linear model: rank of CFU = mean + treatment + position + treatment $*$ position + block nested within treatment + error; block nested within treatment was used as the error term for treatment). This analysis is similar to other nonparametric procedures for less complex designs (6). Linear contrasts were used to examine the differences between treatments and the effects of treatment on the relationship of populations with position in the experimental blocks. The bactericide treatments of the ANOVA represent a partial factorial experiment in which smaller, complete factorial portions can be examined. This factorial nature

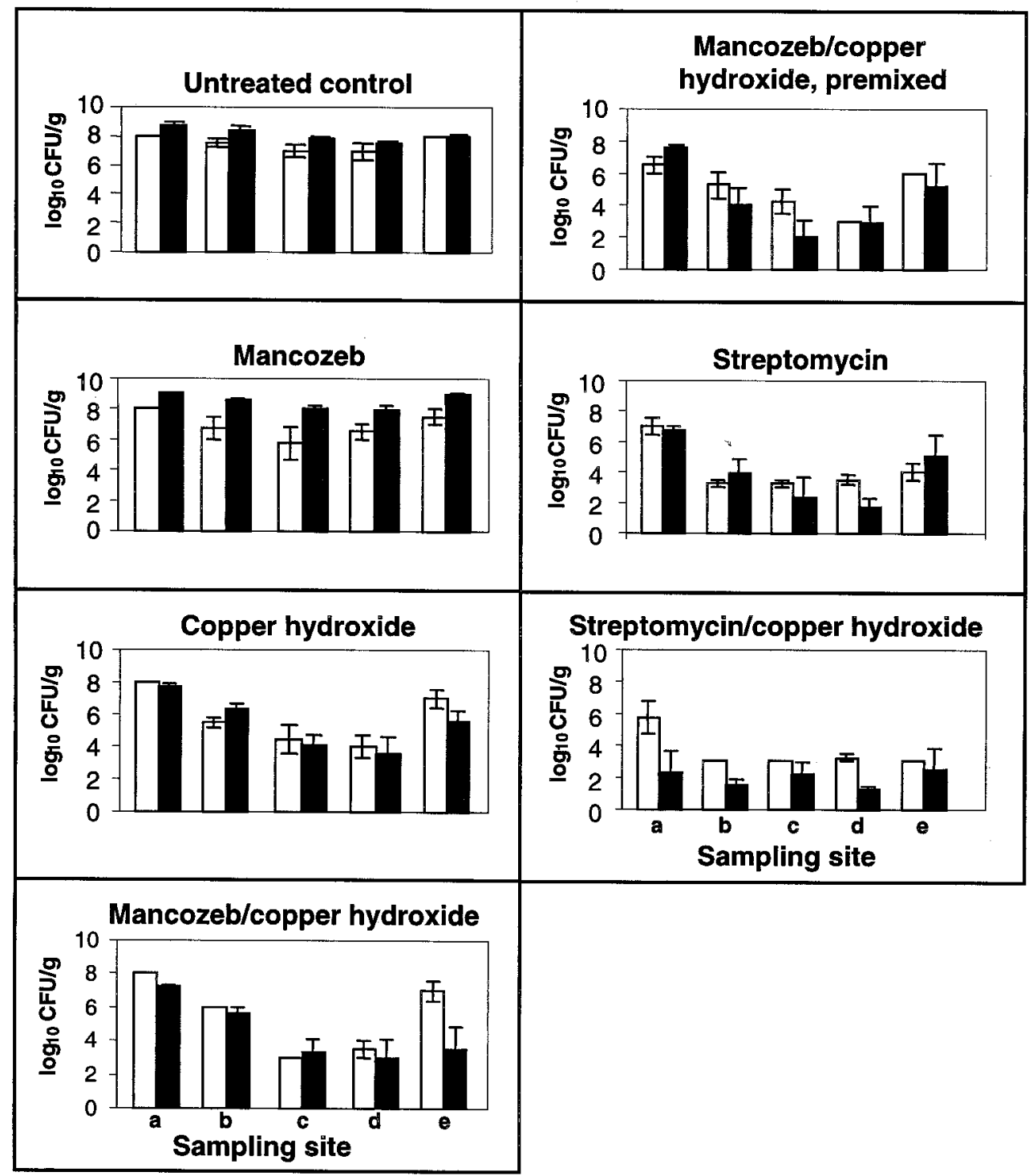

Fig. 2. Clavibacter michiganensis subsp. michiganensis populations (CFU/g) on treated or untreated tomato seedlings in the greenhouse prior to transplanting in the field in 1995 ( $\square$ ) and 1996 (ם) when sampled from sites adjacent to C. michiganensis subsp. michiganensis inoculum foci (a and e), the center of the treatment block (c), and the points in between (b and d). Some standard errors are 0 or too small to print at this scale. 
of the treatments was not examined in the main ANOVA, but was examined using contrasts following the ANOVA results. The first factorial portion examined the role of mancozeb and copper hydroxide by examining the control, mancozeb, copper hydroxide, and copper hydroxide/mancozeb treatments. The second factorial portion investigated the effects of streptomycin and copper hydroxide by examining the control, copper hydroxide, streptomycin, and streptomycin/copper hydroxide treatments. The third factorial portion investigated the difference between mancozeb and streptomycin by examining the mancozeb, copper hydroxide/mancozeb, streptomycin, and streptomycin/copper hydroxide treatments. The premixed copper hydroxide/mancozeb treatment was compared with the copper hydroxide/mancozeb treatment, as well as the streptomycin treatments. Two contrasts were conducted to examine the position effects, one for a linear trend along the positions and one for a quadratic trend. A significant quadratic trend is equivalent to a significant linear relationship with distance. The effect of treatment on position of $C$. michiganensis subsp. michiganensis populations was examined using contrasts involving the interaction between treatment and position.

Field study. On 13 June 1995 and 30 May 1996, 36 seedlings were randomly selected from the center (Fig. 1, region c) of each treatment block and planted in a randomized complete block design at an experimental farm in East Lansing, MI, in sandy loam. The field had previously been planted to dry beans (1994) and sugar beets (1995). Each block consisted of 12 seedlings planted into each of three 3.6-m-long rows spaced $1.5 \mathrm{~m}$ apart with $30.5 \mathrm{~cm}$ between plants within rows. The experimental sites were fertilized and weeds were managed according to standard commercial practices.

To prevent spread of $C$. michiganensis subsp. michiganensis from nearby inoculated plants, uninoculated control plants received streptomycin (Agri-mycin 17, $0.25 \mathrm{~g}$ a.i./liter) applications weekly using a pneumatic handsprayer with a single nozzle operated at $2.8 \mathrm{~kg} / \mathrm{cm}^{2}$ delivering approximately 748 liters/ha. All treatments were sprayed with the fungicide chlorothalonil (Bravo Weather Stik, $2.5 \mathrm{~kg}$ a.i./ha; Zeneca Ag Products, Wilmington, DE) to prevent disease caused by fungal pathogens.

Field sampling of fruit and foliage. On 19 September 1995 and 4 September 1996, plant stand count was recorded for the middle 3.6-m row, and total weight of red and green fruit and incidence of fruit spotting were recorded in a single harvest for the five innermost plants of the middle row. Harvest data were analyzed using ANOVA for a randomized complete block design (Proc GLM). Bactericide treatments were compared using Tukey's procedure for multiple comparisons (21). Foliage from plants was sampled on 18 September 1995 and 3 September 1996 at random
1995
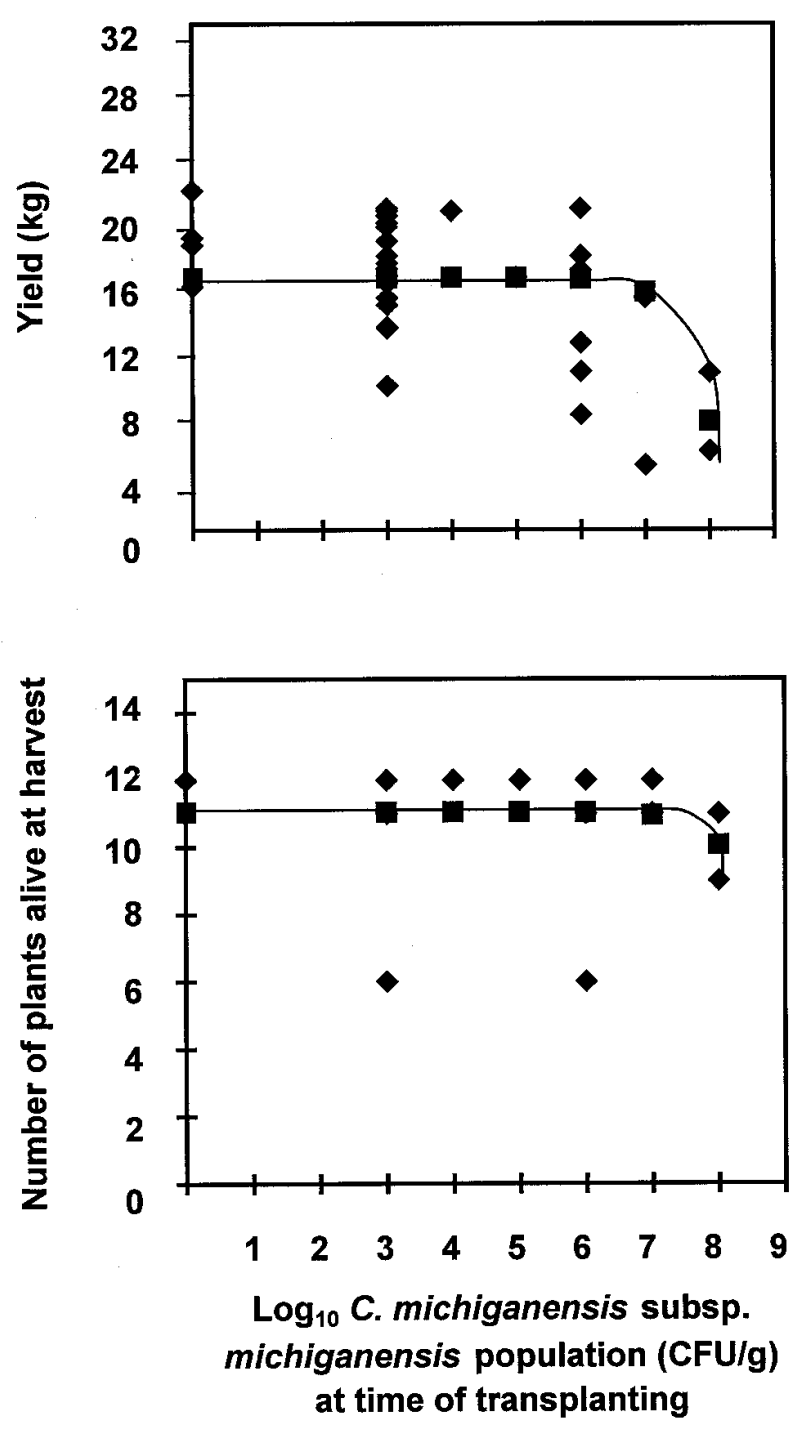

1996
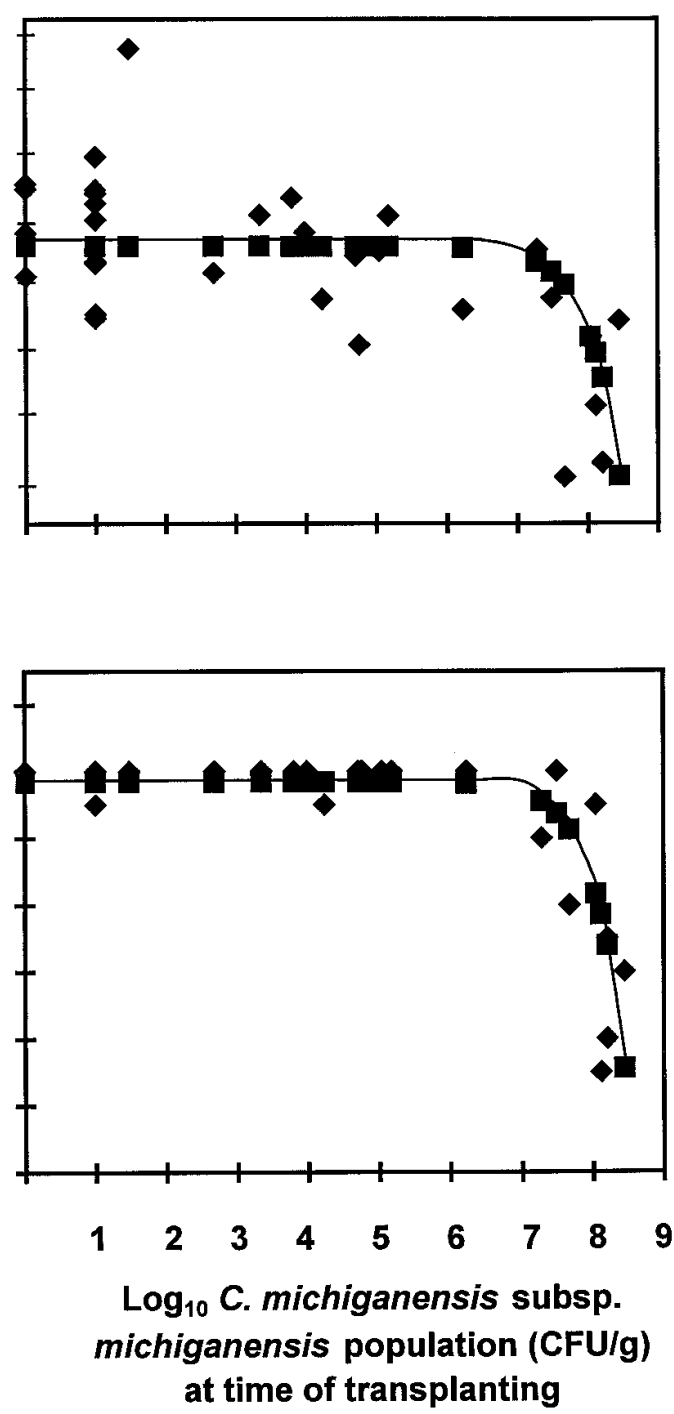

Fig. 3. Calculated regression $(\square)$ and data points $(\diamond)$ for plant yield and transplant survival associated with Clavibacter michiganensis subsp. michiganensis populations on tomato seedlings at the time of transplanting. 
from five to six central plants in the central row of each block and processed as previously described to determine $C$. michiganensis subsp. michiganensis populations and to verify that the field strain was identical to the one used in the greenhouse.

\section{RESULTS}

Impact of bactericides on $C$. michiganensis subsp. michiganensis populations and spread among transplants in the greenhouse. Seedlings directly inoculated with bacteria and introduced into the treatment blocks died during the course of the experiment. White blisters appeared on the leaves of some seedlings within 1 week, with more seedlings developing blisters over time. Both the rifampicin-resistant strain and its parent produced cankers, firing, wilt, and death of tomato seedlings within 3 weeks of inoculation. The same inocula produced a hypersensitive reaction on four o'clock (Mirabilis jalapa) (8). In both years, $C$. michiganensis subsp. michiganensis populations were detected in all treatment blocks in the greenhouse, although disease symptoms were not always apparent.

In both years, treatments differed significantly (1995 and 1996, $P<0.001$ ) in reducing pathogen populations (Fig. 2). The copper hydroxide treatments explained some of these treatment differences when examined in the mancozeb $(1995$ and $1996, P<0.001)$ or streptomycin $(1995, P=0.001 ; 1996, P<0.001)$ factorial portions. The streptomycin treatments also reduced pathogen populations relative to the control $(1995$ and 1996, $P<0.001)$ and relative to mancozeb (1995 and 1996, $P<0.001$ ). Mancozeb, in general, did not reduce $C$. michiganensis subsp. michiganensis populations (1995, $P=0.148 ; 1996, P=0.762)$, but did reduce populations in 1996 when mixed with copper hydroxide $(P=0.009)$. In 1996 only, streptomycin/copper hydroxide lowered pathogen populations $(P=$ 0.005). In both years, premixing copper hydroxide/mancozeb was more effective in limiting pathogen populations than was not premixing $(1995, P<0.001 ; 1996, P<0.001)$. Premixing copper hydroxide/mancozeb was as effective as streptomycin $(1995, P=0.141$; $1996, P=0.390)$, but was not as effective as streptomycin/copper hydroxide $(1995, P=0.008 ; 1996, P<0.001)$.

In both years, position showed both a significant linear (1995 and 1996, $P<0.001)$ and quadratic (1995 and 1996, $P<0.001$ ) trend, indicating that bacterial spread was not uniform across the blocks (Fig. 2). Copper hydroxide affected the linear trend only for the mancozeb factorial portion $(1995, P=0.034 ; 1996, P=$ $0.009)$. The quadratic trend was affected by copper hydroxide in the mancozeb factorial portion $(1995, P<0.001)$ and in conjunction with streptomycin $(1995, P=0.002)$. In 1996 only, premixing copper hydroxide/mancozeb limited bacterial spread (quadratic trend, $P=0.002)$ and differed from not premixing $(P=0.019)$. The quadratic trend for the premixed treatment differed overall from the streptomycin treatments $(P=0.021)$, with this difference being due to the streptomycin/copper hydroxide treatment $(P<0.001)$. Streptomycin effectively limited pathogen spread compared with mancozeb (1995, $P=0.014)$ and copper hydroxide/mancozeb (1995, $P=0.002)$, as indicated by a quadratic trend. Streptomycin also affected the linear trend $(1995, P=0.018 ; 1996, P=0.042)$. In 1996 , streptomycin/copper hydroxide affected the linear $(P=0.046)$ and quadratic $(P=0.002)$ trend.

Impact of bactericides on field productivity. Bacterial populations at region $\mathrm{c}$ in greenhouse plots, in which transplants were used to establish field plots, ranged from $1.0 \times 10^{3}$ to $3.0 \times 10^{8}$ in 1995 and from $1.8 \times 10^{3}$ to $1.4 \times 10^{8}$ in 1996 (Fig. 2) according to treatment. When transplants had pathogen populations approximately $>1 \times 10^{7} \mathrm{CFU} / \mathrm{g}$ of tissue at the end of the transplant cycle (just prior to field establishment), plant survival in the field and fruit yield were reduced (Fig. 3). All treatments, with the exception of mancozeb, limited $C$. michiganensis subsp. michiganensis populations at region c (Fig. 1) to $<5.0 \times 10^{5}$, which is below the threshold $\left(1 \times 10^{7} \mathrm{CFU} / \mathrm{g}\right.$ of tissue $)$ in which plant survival and fruit yield would be adversely affected. However, mancozeb treatment alone did not suppress the pathogen population $\left(>2.6 \times 10^{7}\right.$ $\mathrm{CFU} / \mathrm{g}$ of tissue) in either year, and systemic plant infection and yield reduction occurred.

In 1995 and 1996, none of the bactericide treatments differed significantly from the inoculated control, although the trend was for all bactericide treatments, except mancozeb, to have larger stand counts than that of the inoculated control (Table 1). In both years, surviving plants showed foliar symptoms of bacterial canker including necrosis of the outer leaf edges, or "firing," and brown to tan lesions on peduncles. Final foliar populations at the end of the field season were estimated to be $1.0 \times 10^{8} \mathrm{CFU} / \mathrm{g}$ of tissue for 1995 and ranged from $2.0 \times 10^{8}$ to $2.3 \times 10^{9} \mathrm{CFU} / \mathrm{g}$ of tissue in 1996 . The 1996 uninoculated control had a slightly lower $C$. michiganensis subsp. michiganensis population $\left(1.5 \times 10^{7}\right.$ to $2.3 \times 10^{8} \mathrm{CFU} / \mathrm{g}$ of tissue). In 1995 and 1996, 15 and 29 foliar field isolates, respectively, were subjected to PCR fingerprinting and verified to be the $\mathrm{B}$ type used to inoculate the seedlings in the greenhouse.

Inoculated control plants produced yields that were 63\% (1995) and $51 \%$ (1996) of those produced by the uninoculated controls (Table 1). It was also observed that fruit produced by the inoculated control and mancozeb-treated plants were smaller than that produced by the uninoculated control. In both years, with the exception of mancozeb in 1995, all treatments resulted in yields similar to those obtained with the uninoculated control. In 1995, applications of mancozeb in the greenhouse resulted in a fruit yield statistically similar to that of the inoculated control and significantly smaller than those of all other bactericide treatments. In 1996, while the trend was for all bactericide treatments to have greater yields than that of the mancozeb treatment, only the premixed copper hydroxide/mancozeb and streptomycin/copper hydroxide were statistically different.

TABLE 1. Impact of chemicals applied to tomato seedlings in the greenhouse on field performance including survival, yield, and fruit spotting

\begin{tabular}{|c|c|c|c|c|c|c|}
\hline \multirow[b]{2}{*}{ Treatment $^{\mathrm{v}}$} & \multicolumn{2}{|c|}{ Plant number ${ }^{\mathrm{W}}$} & \multicolumn{2}{|c|}{ Yield (kg/five plants) } & \multicolumn{2}{|c|}{ Diseased fruit (\%) } \\
\hline & 1995 & 1996 & 1995 & 1996 & 1995 & 1996 \\
\hline Uninoculated control $^{\mathrm{x}}$ & $12.0 \mathrm{a}^{\mathrm{y}}$ & $12.0 \mathrm{a}$ & $18.2 \mathrm{a}$ & $19.1 \mathrm{a}-\mathrm{c}$ & $1.4 \mathrm{a}$ & $2.6 \mathrm{c}$ \\
\hline Inoculated control & $10.8 \mathrm{ab}$ & $8.3 \mathrm{ab}$ & $11.4 \mathrm{bc}$ & $9.8 \mathrm{bc}$ & $4.4 \mathrm{a}$ & $19.0 \mathrm{a}-\mathrm{c}$ \\
\hline Mancozeb & $8.8 \mathrm{~b}$ & $7.0 \mathrm{~b}$ & $9.1 \mathrm{c}$ & $8.7 \mathrm{c}$ & $3.8 \mathrm{a}$ & $18.1 \mathrm{a}-\mathrm{c}$ \\
\hline Copper hydroxide & $11.8 \mathrm{ab}$ & $12.0 \mathrm{a}$ & $16.8 \mathrm{ab}$ & $16.2 \mathrm{a}-\mathrm{c}$ & $3.5 \mathrm{a}$ & $34.9 \mathrm{a}$ \\
\hline Copper hydroxide/mancozeb & $11.8 \mathrm{ab}$ & $11.8 \mathrm{a}$ & $15.6 \mathrm{ab}$ & $16.0 \mathrm{a}-\mathrm{c}$ & $4.6 \mathrm{a}$ & $23.7 \mathrm{ab}$ \\
\hline Copper hydroxide/mancozeb ${ }^{z}$ & $11.5 \mathrm{ab}$ & $12.0 \mathrm{a}$ & $16.7 \mathrm{ab}$ & $20.1 \mathrm{ab}$ & $5.4 \mathrm{a}$ & $15.7 \mathrm{bc}$ \\
\hline Streptomycin & $12.0 \mathrm{a}$ & $11.8 \mathrm{a}$ & $16.8 \mathrm{ab}$ & $16.0 \mathrm{a}-\mathrm{c}$ & $1.9 \mathrm{a}$ & $18.1 \mathrm{a}-\mathrm{c}$ \\
\hline Streptomycin/copper hydroxide & $12.0 \mathrm{a}$ & $11.5 \mathrm{a}$ & $19.5 \mathrm{a}$ & $21.8 \mathrm{a}$ & $2.6 \mathrm{a}$ & $9.5 \mathrm{bc}$ \\
\hline
\end{tabular}

${ }^{v}$ Mancozeb (Dithane F-45, $2.3 \mathrm{ml}$ a.i./liter); copper hydroxide (Kocide 40DF, $3.0 \mathrm{~g}$ a.i./liter); and streptomycin (Agri-mycin 17, $0.25 \mathrm{~g}$ a.i./liter). Number of applications were $1 \times / 5$ days = nine sprays in 1995 and eight sprays in 1996.

${ }^{\mathrm{w}}$ Maximum number of plants is 12 .

$\mathrm{x}$ Transplants grown in a separate greenhouse.

y Column means with a letter in common are not significantly different (Tukey's Studentized Range [HSD] test; $P \leq 0.05$ ).

${ }^{\mathrm{z}}$ Mixed $12 \mathrm{~h}$ before application. 
Incidence of fruit with spotting caused by $C$. michiganensis subsp. michiganensis was low in 1995 ( $\leq 5.4 \%$ by weight) compared with 1996, in which a maximum of $34.9 \%$ (by weight) of the fruit were spotted (had at least one spot) (Table 1). In both years, the incidence of fruit with spotting in the uninoculated control plots was low $(\leq 2.6 \%)$. None of the treatments significantly reduced the incidence of fruit spotting compared with that of the inoculated control. In 1995, no treatment differences were observed. For 1996, the only significant difference was observed between copper hydroxide and the uninoculated control. In 1996, three C. michiganensis subsp. michiganensis strains from fruit were subjected to PCR fingerprinting and determined to be type B.

\section{DISCUSSION}

Chemical applications, with the exception of mancozeb, reduced population sizes and spread of $C$. michiganensis subsp. michiganensis among tomato seedlings in the greenhouse and impacted subsequent plant development and yield in the field. Applications of copper hydroxide, copper hydroxide/mancozeb, copper hydroxide/mancozeb (premixed $12 \mathrm{~h}$ before spraying), streptomycin, or streptomycin/copper hydroxide to seedlings in the greenhouse prevented development of severe disease symptoms in the field such as plant and fruit stunting and yield loss.

Pathogen populations of $10^{7} \mathrm{CFU} / \mathrm{g}$ of tissue or higher on seedlings at the end of the greenhouse growing cycle (just prior to planting in the field) occurred on inoculated control and mancozeb-treated seedlings and were associated with systemic infection symptoms in the field including plant stunting and death. Consequently, yield was significantly reduced for the inoculated control and mancozeb treatments by 37 to $54 \%$ compared with that of the uninoculated control. Ricker and Riedel (19) noted yield reductions of 63 to $93 \%$ in processing tomatoes when infected transplants were used to establish fields. Chang et al. (3) reported that decreases in fruit weight and yield of processing tomatoes were related to the incidence of systemic infection due to bacterial canker, with the average fruit weight decreasing as the incidence of systemic infection 1 week before harvest increased.

Pathogen populations on transplants were suppressed below the threshold level ( $10^{7} \mathrm{CFU} / \mathrm{g}$ of tissue), and spread within the greenhouse from the inoculum foci tended to be limited with all chemicals included in this study, with the exception of mancozeb. Copper hydroxide applied alone reduced bacterial populations (1995 and 1996) and tended to reduce spread and, when used in combination with mancozeb, suppressed populations (1996) and limited spread (1995). Premixing copper hydroxide/mancozeb $12 \mathrm{~h}$ prior to application was significantly better than was not premixing in reducing C. michiganensis subsp. michiganensis populations (1995 and 1996) and pathogen spread (1996). Streptomycin was included in our trial as a standard. However, since the streptomycin label does not specify greenhouse use, this bactericide cannot be recommended for use in Michigan even though it was an effective bactericide in our study when used alone or in combination with copper hydroxide.

Copper hydroxide/mancozeb has been shown to enhance control of bacterial diseases and reduce epiphytic bacterial populations compared with using copper alone $(13,16)$. Mixing copper with mancozeb does not increase the soluble copper or ionic copper as suggested by Marco and Stall (16). Rather, the increased bactericidal activity may be due to a synergistic interaction between copper and mancozeb $(13,14)$. Parsons and Edgington (17) determined that there is an antibacterial component in ethylenebisdithiocarbamate (EBDC) fungicides, which they identified as ethylenethiram monosulfide, but use of mancozeb alone in our study did not reduce $C$. michiganensis subsp. michiganensis populations and spread compared with the inoculated control. In our study, there appeared to be an advantage in premixing copper hydroxide/mancozeb $12 \mathrm{~h}$ prior to application versus not premixing.
However, Jones and Jones (12) determined that premixing copper and mancozeb for up to $4 \mathrm{~h}$ prior to application had no effect on bacterial leaf spot control.

Final foliar $C$. michiganensis subsp. michiganensis populations at the end of the field seasons ranged from $1.0 \times 10^{8}$ to $2.3 \times 10^{9}$ CFU/g of tissue among the treatments, with the 1996 uninoculated control having a slightly lower population $\left(1.5 \times 10^{7}\right.$ to $2.3 \times 10^{8}$ $\mathrm{CFU} / \mathrm{g}$ of tissue). All treatments, including the uninoculated control, exhibited leaf margin necrosis. The field populations observed in our study exceeded the leaf surface population of $C$. michiganensis subsp. michiganensis of $10^{6}$ to $10^{7} \mathrm{CFU} / \mathrm{g}$ fresh weight that Chang et al. (4) determined is necessary before symptoms of secondary infection, including spotted fruit and firing of leaflets, occur. In Michigan, bacterial canker symptoms such as necrosis of the leaf margin occur in mid to late season but are seldom associated with economically significant losses (M. K. Hausbeck and D. W. Fulbright, personal observation). Similarly, Ricker and Riedel (17) determined that secondary infection had a relatively minor effect on the yield of processing tomatoes.

"Bird's-eye" fruit spotting occurred regardless of treatment, including the uninoculated control plants that received field applications of streptomycin, indicating pathogen spread within the field. Chang et al. (4) determined that relatively high $\left(10^{7}\right.$ to $10^{9} \mathrm{CFU} / \mathrm{g}$ fresh weight) leaf surface populations of $C$. michiganensis subsp. michiganensis can occur at least $2.7 \mathrm{~m}$ from the focus of infection, resulting in secondary spread and relatively minor disease symptom development. Generally, "birds-eye" spotting does not affect quality of processing tomatoes grown for paste but causes problems in tomatoes processed for whole pack (18). The merit of bactericide sprays in the field warrants further investigation, especially for use in fresh market tomatoes in which blemishes on the fruit are unacceptable.

Oftentimes, applications of bactericides are made in response to disease symptoms occurring in the field. We recommend that applications of copper hydroxide or mancozeb/copper hydroxide be initiated in the greenhouse once seedlings have one set of true leaves and continue on a weekly basis until the seedlings are transplanted to the field. Similarly, Bonn et al. (1) recognized the role of epiphytic Pseudomonas syringae pv. tomato on development of field symptoms and recommended disease control measures in transplant fields. Although the processing tomato industry will not accept produce treated with EBDC fungicides such as mancozeb, occasionally exceptions are made to allow mancozeb use during the seedling stage (M. K. Hausbeck, personal observation).

Observations made in our study regarding epiphytic C. michiganensis subsp. michiganensis populations on tomato transplants may be helpful to the industry in determining the course of action following detection of the pathogen on transplants. Some growers destroy all transplants within an affected greenhouse including those appearing to be healthy, while others destroy symptomatic transplants but plant the healthy-appearing transplants from the same greenhouse. The latter approach can be risky, because greenhouse transplants can appear to be healthy yet have high pathogen populations that are associated with severe disease symptoms in the field. While our results indicate that transplants placed in the field with low pathogen populations will produce commercially acceptable yields, caution should be used in extrapolating our results to fresh market tomatoes or to other tomato-growing regions.

Although major improvements in seed certification and sanitation have been made and growers adhere closely to cultural management recommendations, bacterial canker results in significant economic loss. Field applications of bactericides to control symptoms of bacterial canker, including plant and fruit stunting, wilt, and death, have not been helpful, probably because high pathogen populations were already established on seedlings at the time of transplanting. The results of this study indicate that, to prevent severe bacterial canker disease in the field, growers should initiate and sustain bactericide applications in the greenhouse to suppress 
pathogen populations. While copper alone adequately suppressed C. michiganensis subsp. michiganensis populations and limited spread, copper hydroxide/mancozeb (especially when premixed $12 \mathrm{~h}$ prior to application) provides a comprehensive disease program for commonly occurring fungal pathogens while providing a potentially enhanced level of protection against bacterial pathogens.

\section{ACKNOWLEDGMENTS}

This study was supported by funding from the Michigan Agricultural Experiment Station; Heinz, Inc.; and the Mid-America Processors. We thank S. Linderman for manuscript preparation.

\section{LITERATURE CITED}

1. Bonn, W. G., Gitaitis, R. D., and MacNeill, B. H. 1985. Epiphytic survival of Pseudomonas syringae pv. tomato on tomato transplants shipped from Georgia. Plant Dis. 69:58-60.

2. Chang, R. J., Ries, S. M., and Pataky, J. K. 1991. Dissemination of Clavibacter michiganensis subsp. michiganensis by practices used to produce tomato transplants. Phytopathology 81:1276-1281.

3. Chang, R. J., Ries, S. M., and Pataky, J. K. 1992. Reductions in yield of processing tomatoes and incidence of bacterial canker. Plant Dis. 76: 805-809.

4. Chang, R. J., Ries, S. M., and Pataky, J. K. 1992. Local sources of Clavibacter michiganensis ssp. michiganensis in the development of bacterial canker on tomatoes. Phytopathology 82:553-560.

5. Conover, R. A., and Gerhold, N. R. 1981. Mixtures of copper and maneb or mancozeb for control of bacterial spot of tomato and their compatibility for control of fungus diseases. Proc. Fla. State Hortic. Soc. 94:154-156.

6. Conover, W. J. 1980. Practical Nonparametric Statistics, 2nd ed. Wiley, New York.

7. Farley, J. D., and Miller, T. D. 1973. Spread and control of Corynebacterium michiganense in tomato transplants during clipping. Plant Dis. Rep. 57:767-769.

8. Gitaitis, R. D. 1990. Induction of a hypersensitivelike reaction in fouro'clock by Clavibacter michiganensis subsp. michiganensis. Plant Dis. 74:58-60.

9. Gitaitis, R. D., Beaver, R. W., and Voloudakis, A. E. 1991. Detection of
Clavibacter michiganensis subsp. michiganensis in symptomless tomato transplants. Plant Dis. 75:834-838.

10. Gleason, M. L., Gitaitis, R. D., and Ricker, M. D. 1993. Recent progress in understanding and controlling bacterial canker of tomato in eastern North America. Plant Dis. 77:1069-1076.

11. Jones, J. B., and Jones, J. P. 1983. Bacterial leaf spot diseases on tomatoes in Florida and the control of two such diseases with bactericides. Proc. Fla. State Hortic. Soc. 96:101-103.

12. Jones, J. B., and Jones, J. P. 1985. The effect of bactericides, tank mixing time and spray schedule on bacterial leaf spot of tomato. Proc. Fla. State Hortic. Soc. 98:244-247.

13. Jones, J. B., Woltz, S. S., Jones, J. P., and Portier, K. L. 1991. Population dynamics of Xanthomonas campestris pv. vesicatoria on tomato leaflets treated with copper bactericides. Phytopathology 81:714-719.

14. Jones, J. B., Woltz, S. S., Kelly, R. O., and Harris, G. 1991. The role of ionic copper, total copper, and select bactericides on control of bacterial spot of tomato. Proc. Fla. State Hortic. Soc. 104:257-259.

15. Louws, F. J., Bell, J., Medina-Mora, C. M., Smart, C. D., Opgenorth, D., Ishimaru, C. A., Hausbeck, M. K., de Bruijn, F. J., and Fulbright, D. W. 1998. rep-PCR-mediated genomic fingerprinting: A rapid and effective method to identify Clavibacter michiganensis. Phytopathology 88:862868.

16. Marco, G. M., and Stall, R. E. 1983. Control of bacterial spot of pepper initiated by strains of Xanthomonas campestris pv. vesicatoria that differ in sensitivity to copper. Plant Dis. 67:779-781.

17. Parsons, I. M., and Edgington, L. V. 1981. The possible role of fixed coppers in combination with ethylenebisdithiocarbamates for control of Pseudomonas syringae pv. tomato. (Abstr.) Phytopathology 71:563.

18. Ricker, M. D., and Riedel, R. M. 1988. Economic importance of secondary spread of Clavibacter michiganensis subsp. michiganensis in northern-grown processing tomatoes. (Abstr.) Phytopathology 78:1570.

19. Ricker, M. D., and Riedel, R. M. 1993. Effect of secondary spread of Clavibacter michiganensis subsp. michiganensis on yield of northern processing tomatoes. Plant Dis. 77:364-366.

20. Shoemaker, P. B. 1992. Evaluation of different materials for tomato bacterial canker, 1991. Fungic. Nematic. Tests 47:155.

21. Steel, R. G. D., Torrie, J. H., and Dickey, D. A. 1996. Principles and Procedures of Statistics: A Biometrical Approach, 3rd ed. McGraw-Hill, Inc., New York.

22. Strider, D. L. 1969. Bacterial canker of tomato, a literature review and bibliography. N.C. Agric. Exp. Stn. Tech. Bull. 193. 